\title{
THE DEBT-EQUITY CHOICE OF JAPANESE FIRMS
}

\author{
Terence Tai-Leung Chong* \\ The Chinese University of Hong Kong \\ Nanjing University \\ Daniel Tak-Yan Law \\ The Chinese University of Hong Kong \\ Feng Yao \\ West Virginia University \\ Guangdong University of Foreign Studies
}

\begin{abstract}
Prior studies on the debt-equity choice of firms focus on capital market oriented economies. This paper examines whether firms in Japan, the world's largest bank-oriented economy, adjust their debt-equity choice towards the target. We find that the leverage ratios of Japanese firms do adjust slowly towards their target levels. The adjustment speed has dwindled after the Asian Financial Crisis. In contrast to existing literature, we show that an increase in tangible assets reduces the leverage ratio of firms in Japan. It is also found that the effect of financial deficit is persistent while the market timing effect is not.
\end{abstract}

Keywords: Debt-equity Choice; Pecking Order Theory; Market Timing Theory; Trade-Off Theory.

\section{INTRODUCTION}

The selection of target debt-equity ratio has received increasing attention in recent years. One strand of the literature focuses on the determinants of the optimal target ratio (Graham and Harvey, 2001; Hovakimian et al., 2001; Booth et al., 2001; Baker and Wurgler, 2002; Frank and Goyal, 2003). There are three major competing theories explaining firms' debt-equity choice in the literature. The trade-off theory suggests that the optimal debt-equity choice of a firm can be determined by looking at the trade-offs between costs and benefits of financing through debt and equity. The pecking order theory states that firms prefer internal financing by retained earnings to external financing, and

\footnotetext{
*Corresponding Author: Terence Tai-Leung Chong, Department of Economics, The Chinese University of Hong Kong, Shatin, N.T., Hong Kong. Email: chong2064@cuhk.edu.hk. Webpage: http://www.cuhk.edu.hk/eco/staff/tlchong/tlchong3.htm.
} 
prefer debt to equity for external financing. ${ }^{1}$ The market timing theory argues that firms tend to issue equity under good market condition. ${ }^{2}$ Another strand of the literature investigates how the leverage ratio moves towards the target. ${ }^{3}$ A representative study is Kayhan and Titman (2007), which examines the adjustment of debt-equity choice of US firms over a five-year horizon. They show that cash flows, investment expenditure and stock performance lead to deviations from the target ratio, and that the debt-equity choice adjusts towards the target ratio in the long run. The results of Kayhan and Titman (2007) apply to firms in a capital market oriented economy.

In this paper, we examine the debt-equity choice of Japanese firms. The case of Japan is of interest because Japan is the largest bank-oriented economy in the world. A model containing variables associated with the tradeoff, pecking order and market timing theories will be estimated to evaluate the impact of different factors on the adjustment of book and market target leverage ratios. The persistence and reversal of the effects will also be analyzed.

Some new results are obtained. First, in contrast to expectation, we find that an increase in tangible assets reduces the leverage ratio of firms in Japan. Second, we provide new evidence that these firms do adjust their leverage ratio to target in the long run. Third, we conclude that the market timing effect is not persistent in the case of Japan. In addition, we also show that the adjustment speed of the debt ratio for firms in Japan has dwindled after the Asian financial crisis.

The structure of the paper is organized as follows: Section 2 describes the data and methodology. Section 3 presents the empirical results. Section 4 is the conclusion.

\section{DATAAND METHODOLOGY}

Annual data for industrial firms with more than ten-year business operation over the period 1980 - 2003, are extracted from the PACAP database. The sample consists of 1,299 Japanese firms, excluding financial firms, firms with a leverage ratio greater than 1 , and firms with a market-to-book ratio greater than 10 . The descriptive statistics of firm characteristics are reported in Table 1.

\footnotetext{
${ }^{1}$ The pecking order hypothesis was proposed by Donaldson (1961) and Myers (1984). Shyam-Sunder and Myers (1999), Frank and Goyal (2003) and Brounen et al. (2006) provide supporting evidence for this hypothesis.

${ }^{2}$ Under this theory, firms with a high market-to-book ratio will have a low debt ratio (Baker and Wurgler, 2002; Welch, 2004).

${ }^{3}$ See, for example, Fischer, Heinkel and Zechner (1989), Goldstein, Ju and Leland (2001), Collin-Dufresne and Goldstein (2001), Korajczyk and Levy (2003) and Flannery and Rangan (2006).
} 
Compared with other Asian countries, Japan has relatively high average book leverage ratio and average market leverage ratio, 0.5239 and 0.4672 respectively. Note that the mean fixed asset ratio is 0.2453 , the mean financial deficit is -0.1499 , and the mean current ratio is 1.6612. These last three ratios are below average levels of other Asian countries.

Table 1: Descriptive Statistics of variables estimating the target leverage

\begin{tabular}{|c|c|c|c|c|c|}
\hline Variable & Definition & Mean & Std. Err. & 95\% Conf & Interval \\
\hline Book Leverage Ratio & $\begin{array}{l}\text { total liabilities divided by the } \\
\text { book value of assets }\end{array}$ & 0.5239 & 0.0059 & 0.5124 & 0.5354 \\
\hline Market Leverage Ratio & $\begin{array}{l}\text { total liabilities divided by the } \\
\text { market value of assets }\end{array}$ & 0.4672 & 0.0058 & 0.4559 & 0.4785 \\
\hline $\begin{array}{l}\text { Fixed Asset Ratio } \\
\text { (TANG) }\end{array}$ & $\begin{array}{l}\text { the ratio of total fixed assets to } \\
\text { total assets of a firm. }\end{array}$ & 0.2453 & 0.0033 & 0.2387 & 0.2518 \\
\hline $\begin{array}{l}\text { EBIT(scaled by the } \\
\text { book asset) }\end{array}$ & $\begin{array}{l}\text { scaling the earnings before } \\
\text { interest and taxes by the book } \\
\text { value of assets }\end{array}$ & 0.0474 & 0.0009 & 0.0456 & 0.0492 \\
\hline $\begin{array}{l}\text { EBIT (scaled by the } \\
\text { sum of market equity } \\
\text { and book debt) }\end{array}$ & $\begin{array}{l}\text { scaling the earnings before } \\
\text { interest and taxes by the market } \\
\text { value of assets }\end{array}$ & 0.0324 & 0.0006 & 0.0312 & 0.0335 \\
\hline $\begin{array}{l}\text { Logarithm of Firm } \\
\text { Size (SIZE) }\end{array}$ & the logarithm of total assets & 10.8995 & 0.0346 & 10.8316 & 10.9674 \\
\hline Current Ratio (LIQ) & $\begin{array}{l}\text { the ratio of current assets and } \\
\text { current liabilities }\end{array}$ & 1.6612 & 0.0270 & 1.6083 & 1.7142 \\
\hline $\begin{array}{l}\text { 1-year Stock return } \\
\text { (RETURN) }\end{array}$ & $\begin{array}{l}\text { the first difference of the } \\
\text { logarithm of annual share prices }\end{array}$ & -0.0145 & 0.0018 & -0.0180 & -0.0109 \\
\hline Financial deficit (FD) & $\begin{array}{l}\text { the sum of the net equity and net } \\
\text { debt issued between year t-i and } t \\
\text { scaled by the total assets in year } \\
\text { t-i }\end{array}$ & -0.1499 & 0.0134 & -0.1762 & -0.1236 \\
\hline $\begin{array}{l}\text { Market -to-book ratio } \\
(\mathrm{M} / \mathrm{B})\end{array}$ & $\begin{array}{l}\text { the ratio of market value and the } \\
\text { book value of total assets. }\end{array}$ & 1.4035 & 0.0120 & 1.3798 & 1.4271 \\
\hline $\begin{array}{l}\text { Non-debt tax shield } \\
\text { (NDTS) }\end{array}$ & $\begin{array}{l}\text { the ratio between depreciation } \\
\text { and total assets. }\end{array}$ & 0.0277 & 0.0005 & 0.0267 & 0.0287 \\
\hline $\begin{array}{l}\text { Earning volatility } \\
\text { (VOL) }\end{array}$ & $\begin{array}{l}\text { the absolute difference between } \\
\text { the annual percentage change in } \\
\text { earnings before interest and taxes } \\
\text { and the average of this change } \\
\text { over the sample period. }\end{array}$ & 1.8829 & 0.1992 & 1.4921 & 2.2737 \\
\hline \multicolumn{2}{|l|}{ Number of observations } & \multicolumn{4}{|c|}{1299} \\
\hline
\end{tabular}




\subsection{Estimation of the Target Leverage Ratio}

To investigate the relationship between the debt-equity choice of a Japanese firm and its characteristics, the following model of the leverage ratio $L_{t}$ is investigated:

$$
\begin{aligned}
\mathrm{L}_{\mathrm{t}}= & \alpha_{0}+\beta_{1} \text { TANG }_{\mathrm{t}}+\beta_{2} \text { EBIT }_{\mathrm{t}}+\beta_{3} \text { SIZE }_{\mathrm{t}}+\beta_{4} \mathrm{LIQ}_{\mathrm{t}}+\beta_{5} \text { RETURN }_{\mathrm{t}} \\
& +\beta_{6} \mathrm{M} / \mathrm{B}_{\mathrm{t}}+\beta_{7} \text { NDTS }_{\mathrm{t}}+\beta_{8} \text { VOL }_{\mathrm{t}}+\beta_{9} \text { Industry dummies }_{\mathrm{t}}+\mathrm{e}_{\mathrm{t}}
\end{aligned}
$$

$L_{t}$ is the leverage ratio,

TANG is the average fixed asset ratio,

$E B I T$ is the average earning before interest and taxes scaled by total assets,

SIZE is the logarithm of average total assets,

$L I Q$ is average current ratio,

$R E T U R N$ is average one-year stock return,

$M / B$ is the average market-to-book ratio,

NDTS is average non-debt tax shield, and

$V O L$ is the average volatility of earnings.

Both the book and market leverage regressions are estimated. The book leverage ratio is calculated by dividing total liabilities by total assets at book value, which equals the sum of equity and liabilities at book value. For consistency, we scale all firm-specific variables based on its total assets. The market leverage ratio is percentage of total liabilities to total assets at market value. The market value of assets is defined as the sum of market value of equity and the book value of total liabilities.

The average fixed asset ratio (TANG) shows the proportion of a firm's total fixed assets to its total assets. As tangible assets are eligible collateral for most loans and have good liquidity, their presence reduces default risks in bank lending. Therefore, we expect a positive relationship between values of tangible assets and target leverage. The variable EBIT, which measures return on asset, is used as a proxy of profitability, which is calculated by scaling the earnings before interest and taxes by the book value of assets in the book leverage regression, and by the market value of assets in the market leverage regression. For a firm that prefers internal funds, its debt ratio reduces as its past earnings before interest and taxes (EBIT) increases. The variable, SIZE, is the logarithm of total assets. The market-to-book ratio (M/B) is the ratio of market value to the book value of total assets. Non-debt tax shield (NDTS) is the proportion of depreciation to total assets. DeAngelo and Masulis (1980) argue that a higher non-tax debt shield, such as depreciation, adds to the difficulties of debt financing. Therefore, we expect a negative relationship between non-debt tax shields and target leverage.

The current ratio of a firm, which is the ratio of current assets to current liabilities, is used to measure its liquidity (LIQ). We define the volatility of earnings (VOL) as the absolute difference between the annual percentage change in earnings before interest and taxes 
(EBIT) and the average of this change over the sample period. The annual stock return (RETURN) is the first difference of the logarithm of annual share prices. Industry dummies are added to control for the industry specific effect. ${ }^{4}$ All the regressors, except the industry dummies, are calculated by taking averages over the sample period for each firm. ${ }^{5}$

\subsection{Long-term Adjustment}

Kayhan and Titman (2007) analyze the determinants of the change in leverage ratio over a 5 -year horizon using a two-step linear regression. ${ }^{6}$ In this paper, we consider the change of leverage ratio within 3, 4, and 5-year horizons. We will also examine 10-year persistence and reversal effects. The following models are estimated for both changes in book and market leverages:

$$
\begin{aligned}
\mathrm{L}_{\mathrm{t}}-\mathrm{L}_{\mathrm{t}-\mathrm{i}}= & \alpha_{0}+\beta_{1} \mathrm{FDd}_{\mathrm{t}-\mathrm{i}, \mathrm{t}}+\beta_{2} \mathrm{FD}_{\mathrm{t}-\mathrm{i}, \mathrm{t}}+\beta_{3} \mathrm{YT}_{\mathrm{t}-\mathrm{i}, \mathrm{t}}+\beta_{4} \mathrm{LT}_{\mathrm{t}-\mathrm{i}, \mathrm{t}}+\beta_{5} \mathrm{r}_{\mathrm{t}-\mathrm{i}, \mathrm{t}}+\beta_{6} \mathrm{EBIT}_{\mathrm{t}-\mathrm{i}, \mathrm{t}} \\
& +\beta_{7} \text { Ldef }_{\mathrm{t}-\mathrm{i}}+\beta_{8} \Delta \operatorname{Target}_{\mathrm{t}-\mathrm{i}}+\beta_{9} \text { Industry dummies }+\beta_{10} \text {CRISIS }+\mathrm{e}_{\mathrm{t}},
\end{aligned}
$$

$F D d_{t-i, t}$ is a dummy for positive $F D_{t-i, t}$,

$F D_{t-i, t}$ is financial deficit over the past $i$ years,

$Y T_{t-i, t}$ is a yearly timing measure for $i$ years,

$L T_{t-i, t}$ is a long-term timing measure for $i$ years,

$r_{t-i, t}$ is the stock return from year $t-i$ to year $t$,

$E B I T_{t-i, t}$ is the earnings before interest and taxes over the past $i$ years,

$L d e f_{t-i}$ is the leverage deficit of year $t-i$, and

$\Delta$ Target $_{t-i}$ is the change of the target leverage ratio over the past $i$ years,

where $i=3,4,5 . F D_{t-i, t}$ is the financial deficit, which is defined as the sum of the net equity and net debt issued between year $\mathrm{t}-\mathrm{i}$ and $\mathrm{t}$, scaled by the total assets in year t-i. $\mathrm{FDd}_{\mathrm{t}-\mathrm{i}, \mathrm{t}}$ is binary variable, which equals one when $\mathrm{FD}_{\mathrm{t}-\mathrm{i}, \mathrm{t}}$ is positive, and equals zero otherwise. $\mathrm{YT}_{\mathrm{t}-\mathrm{i}, \mathrm{t}}$ is a yearly timing measure, which is the sample covariance between the financial deficit and the market-to-book ratio from year t-i to t. $\mathrm{LT}_{\mathrm{t}-\mathrm{i}, \mathrm{t}}$ is a long-term timing measure, which is product of the average market-to-book ratio and average financial deficit between year t-i and t. ${ }^{7} r_{t-i, t}$ is the cumulative stock return from year t-i to t. EBIT $_{t-i, t}$ is

\footnotetext{
${ }^{4}$ Eight industry dummies are employed to control for sector specific effects. Sectors under study include primary sector, house leasing, manufacturing, raw material, utilities, real estate, wholesale and retail, and other industries.

${ }^{5}$ The method is similar to that of Fama-Macbeth (1973).

${ }^{6}$ In the first step, they estimate the target leverage ratio by using traditional trade-off variables as described in Section 2.1. The leverage deficit variable is estimated as the difference between the actual leverage ratio and target leverage ratio at the beginning of the period. In the second step, the 5-year change of leverage ratio is regressed against the estimated leverage deficit, changes in the target debt ratio and other variables.

${ }^{7}$ Specifically, $\mathrm{YT}_{\mathrm{t}-\mathrm{i}, \mathrm{t}}=\operatorname{Cov}(\mathrm{FD}, \mathrm{M} / \mathrm{B}), \mathrm{LT}_{\mathrm{t}-\mathrm{i}, \mathrm{t}}=($ avg. $\mathrm{FD})($ avg. $\mathrm{M} / \mathrm{B})$.
} 
defined as the sum of earnings before interest and taxes between year t-i and $t$. Ldef $_{t-i}$ is the estimated leverage deficit of year $\mathrm{t}-\mathrm{i}$, defined as the difference between leverage at year $\mathrm{t}-\mathrm{i}$ and target leverage for the same period. $\Delta$ Target $_{\mathrm{t}-\mathrm{i}}$ is the change of the estimated target leverage ratio between year t-i and t. We include a binary variable CRISIS, which equals 1 for years after 1997, and equal 0 otherwise, to capture the effects of 1997 Asian Financial Crisis. ${ }^{8}$ Our model includes the variables for the tradeoff theory (Ldef $\mathrm{L}_{\mathrm{t}-\mathrm{i}}$ and $\Delta$ Target $\left._{\mathrm{t}-\mathrm{i}}\right)$, pecking order theory $\left(\mathrm{FD}_{\mathrm{t}-\mathrm{i}, \mathrm{t}}\right.$ and $\left.\mathrm{EBIT}_{\mathrm{t}-\mathrm{i}, \mathrm{t}}\right)$ and market timing theory $\left(\mathrm{YT}_{\mathrm{t}-\mathrm{i}, \mathrm{t}}\right.$, $\mathrm{LT}_{\mathrm{t}-\mathrm{i}, \mathrm{t}}$ and $\mathrm{r}_{\mathrm{t}-\mathrm{i}, \mathrm{t}}$ ). For consistency, the same sample is used throughout this paper. ${ }^{9}$

\subsubsection{Tradeoff Theory}

The explanatory variables for the tradeoff theory (Hovakimian et al., 2001; Fama and French, 2002) include leverage deficit ( Ldef $\left._{\mathrm{t}-\mathrm{i}}\right)$ and change in target ratio ( $\Delta$ Target $\left._{\mathrm{t}-\mathrm{i}}\right)$. For example, according to trade-off theory, firms will reduce their leverage ratios when they are higher than target ratios. In this case, the long-term adjustment of leverage ratio towards the target is indicated by the negative coefficient of Ldef $_{\mathrm{t}-\mathrm{i}}$. If the cost of adjustment is high, the magnitude of the coefficient should be small. Conversely, a low cost of adjustment should result in a large coefficient.

\subsubsection{Pecking Order Theory}

It has been observed that firms with a higher financial deficit have a higher leverage ratio (Shyam-Sunder and Myers, 1999; Frank and Goyal, 2003). In our model, a positive coefficient of the financial deficit $\left(\mathrm{FD}_{\mathrm{t}-\mathrm{i}, \mathrm{t}}\right)$ variable implies the existence of the pecking order effect. As positive financial deficit may affect the debt-equity choice differently from a negative one, a binary $\mathrm{FDd}_{\mathrm{t}-\mathrm{i}, \mathrm{t}}$ is added to the model in order to capture the effects of this difference. It indicates whether there is a financial deficit between year t-i and t. Profitability is approximated by the scaled cumulative earnings before interest and taxes $\left(\mathrm{EBIT}_{\mathrm{t}-\mathrm{i}, \mathrm{t}}\right)$ between year $\mathrm{t}-\mathrm{i}$ and $\mathrm{t} .{ }^{10}$ We expect a negative impact of $\mathrm{EBIT}_{\mathrm{t}-\mathrm{i}, \mathrm{t}}$ on the change in leverage ratio under the pecking order theory.

\subsubsection{Market Timing Theory}

Baker and Wurgler (2002) construct an external finance weight-average market-to-book

\footnotetext{
${ }^{8}$ To address the heteroskedasticity and autocorrelation problems, we use the bootstrap method to obtain the standard errors of coefficient estimates.

${ }^{9}$ Kayhan and Titman (2007) use different samples to investigate the contemporaneous, persistence, and reversal effects of financial deficit, market conditions and profitability on the debt ratio. We use the same sample throughout this paper.

${ }^{10}$ As pointed out by Kayhan and Titman (2007), the existence of profits indicates that the availability of internal funds has an independent impact on debt-equity choice even after controlling for the financial deficit.
} 
ratio $\left(\mathrm{M} / \mathrm{B}_{\mathrm{EFWA}}\right)$ to measure the overvaluation of equity and the market timing effect. ${ }^{11}$ Kayhan and Titman (2007) show that $\mathrm{M} / \mathrm{B}_{\mathrm{EFWA}}$ can be decomposed into two components: a yearly timing variable $\left(\mathrm{YT}_{\mathrm{t}-\mathrm{i}, \mathrm{t}}\right)$ scaled by average financial deficit, and the average market-to-book ratio (or $\mathrm{LT}_{\mathrm{t}-\mathrm{i}, \mathrm{t}}$ divided by average financial deficit). The first component is invariant to the amount of capital raised. The second component introduces a negative relationship between $\mathrm{M} / \mathrm{B}_{\mathrm{EFWA}}$ and changes in leverage ratio for reasons other than market timing motivation. In this paper, we also include these two variables in our model. The yearly timing variable $\left(\mathrm{YT}_{\mathrm{t}-\mathrm{i}, \mathrm{t}}\right)$, defined as the sample covariance between yearly financial deficit and market-to-book ratio between year t-i and $t$, is included to capture the market timing effect. It indicates whether firms will take advantage of short-term overvaluation to raise funds by issuing equity, and captures the effects of market timing on debt-equity choice of a firm that raises more external capital. A negative relationship is expected between yearly timing and the change in debt ratio when the market timing strategy is in effect. The long-term timing variable $\left(\mathrm{LT}_{\mathrm{t}-\mathrm{i}, \mathrm{t}}\right)$ is also included.

We add $\mathrm{r}_{\mathrm{t}-\mathrm{i}, \mathrm{t}}$ in the regression to further investigate the separate effect of stock returns on the change of leverage ratio. A negative impact of stock returns on market leverage is expected if firms are more willing to issue equity when stock performance is good or when the market valuation is high.

\subsection{Persistence and Reversal of Effects}

To see continuous effects of influencing factors on long-term adjustment, we examine how the change of observed leverage ratio over a 2i-year horizon is affected by the variables in the two separate i-year periods. Specifically, we consider

$$
\begin{aligned}
\mathrm{L}_{\mathrm{t}}-\mathrm{L}_{\mathrm{t}-2 \mathrm{i}}= & \alpha_{0}+\beta_{1} \mathrm{FDd}_{\mathrm{t}-2 \mathrm{i}, \mathrm{t}-\mathrm{i}}+\beta_{2} \mathrm{FD}_{\mathrm{t}-2 \mathrm{i}, \mathrm{t}-\mathrm{i}}+\beta_{3} \mathrm{YT}_{\mathrm{t}-2 \mathrm{i}, \mathrm{t}-\mathrm{i}}+\beta_{4} \mathrm{LT}_{\mathrm{t}-2 \mathrm{i}, \mathrm{t}-\mathrm{i}}+\beta_{5} \mathrm{r}_{\mathrm{t}-2 \mathrm{i}, \mathrm{t}-\mathrm{I}}+\beta_{6} \mathrm{EBIT}_{\mathrm{t}-2 \mathrm{i}, \mathrm{t}-\mathrm{i}} \\
& +\beta_{7} \mathrm{FDd}_{\mathrm{t}-\mathrm{i}, \mathrm{t}}+\beta_{8} \mathrm{FD}_{\mathrm{t}-\mathrm{i}, \mathrm{t}}+\beta_{9} \mathrm{YT}_{\mathrm{t}-\mathrm{i}, \mathrm{t}}+\beta_{10} \mathrm{LT}_{\mathrm{t}-\mathrm{i}, \mathrm{t}}+\beta_{11} \mathrm{r}_{\mathrm{t}-\mathrm{i}, \mathrm{t}}+\beta_{12} \mathrm{EBIT}_{\mathrm{t}-\mathrm{i}, \mathrm{t}} \\
& +\beta_{13} \mathrm{Ldef}_{\mathrm{t}-\mathrm{i} \mathrm{i}}+\beta_{14} \Delta \text { Target }_{\mathrm{t}-2 \mathrm{i}}+\beta_{15} \text { Industry dummies }+\beta_{16} \mathrm{CRISIS} \mathrm{e}_{\mathrm{t},}
\end{aligned}
$$

where $\mathrm{i}=3,4,5$.

If the effect is persistence, the parameter in the first i-year period should be significant and have the same sign as in the following i-year period. The parameters are estimated using ordinary least squares (OLS) method and the standard errors are calculated via bootstrapping. To see whether firms are taking offsetting actions to prevent themselves from moving away from the target leverage ratio, we directly test the reversal effect. We

\footnotetext{
11 The weight-average market-to-book ratio ( $\left.\mathrm{M} / \mathrm{B}_{\mathrm{EFWA}}\right)$ is defined as $M / B_{E F W A}=\sum_{s=0}^{t-1} \frac{F D_{s}}{\sum_{r=0}^{t-1} F D_{r}}(M / B)_{s}$ where $F D_{s}$ is the financial deficit, and $(\mathrm{M} / \mathrm{B})_{\mathrm{s}}$ is the market-to-book
} ratio in year s. When $M / B_{E F W A}$ is high, the stock is overvalued and the firm is likely to issue equity. 
modify (3) by replacing the dependent variable with the change of leverage ratio in i years instead of $2 \mathrm{i}$ years. Specifically, we estimate

$$
\begin{aligned}
\mathrm{L}_{\mathrm{t}}-\mathrm{L}_{\mathrm{t}-\mathrm{i}}= & \alpha_{0}+\beta_{1} \mathrm{FDd}_{\mathrm{t}-2 \mathrm{i}, \mathrm{t}-\mathrm{I}}+\beta_{2} \mathrm{FD}_{\mathrm{t}-2 \mathrm{i}, \mathrm{t}-\mathrm{I}}+\beta_{3} \mathrm{YT}_{\mathrm{t}-2 \mathrm{i}, \mathrm{t}-\mathrm{I}}+\beta_{4} \mathrm{LT}_{\mathrm{t}-2 \mathrm{i}, \mathrm{t}-\mathrm{i}}+\beta_{5} \mathrm{r}_{\mathrm{t}-2 \mathrm{i}, \mathrm{t}-\mathrm{I}}+\beta_{6} \mathrm{EBIT}_{\mathrm{t}-\mathrm{i}, \mathrm{t}-\mathrm{i}} \\
& +\beta_{7} \mathrm{FDd}_{\mathrm{t}-\mathrm{i}, \mathrm{t}}+\beta_{8} \mathrm{FD}_{\mathrm{t}-\mathrm{i}, \mathrm{t}}+\beta_{9} \mathrm{YT}_{\mathrm{t}-\mathrm{i}, \mathrm{t}}+\beta_{10} \mathrm{LT}_{\mathrm{t}-\mathrm{i}, \mathrm{t}}+\beta_{11} \mathrm{r}_{\mathrm{t}-\mathrm{i}, \mathrm{t}}+\beta_{12} \mathrm{EBIT}_{\mathrm{t}-\mathrm{i}, \mathrm{t}}+ \\
& \beta_{13} \mathrm{Ldef}_{\mathrm{t}-2 \mathrm{i}}+\beta_{14} \Delta \text { Target }_{\mathrm{t}-\mathrm{ii}}+\beta_{15} \text { Industry dummies }+\beta_{16} \mathrm{CRISIS} \mathrm{e}_{\mathrm{t}}
\end{aligned}
$$

where $\mathrm{i}=3,4,5$.

Essentially, the change of leverage in i years is regressed against variables in the two separate i-year periods. If a reversal exists, the signs of the same variable should be different in the first and second i-year periods. ${ }^{12}$

\section{RESULTS}

\subsection{Estimation of the Target Ratio}

Both the book and market leverage ratios respectively are regressed against averaged firm characteristics for the 1980 - 2003 sample period. The results are reported in Table 2.

Table 2: Estimation Results for the Target Book Leverage and Market Leverage Ratios (Model 1)

\begin{tabular}{ccc}
\hline \hline $\boldsymbol{L}_{\boldsymbol{t}}$ & Book Leverage & Market Leverage \\
\hline constant & $0.6836(16.5)^{*}$ & $0.9033(22.5)^{*}$ \\
TANG & $-0.1099(-2.2)^{*}$ & $-0.0639(-1.3)$ \\
EBIT & $-1.7531(-12.3)^{*}$ & $-1.8475(-9.2)^{*}$ \\
SIZE & $0.0163(4.9)^{*}$ & $0.0052(1.6)$ \\
LIQ & $-0.1163(-24.8)^{*}$ & $-0.0966(-21.7)^{*}$ \\
$R E T U R N$ & $-0.2278(-3.6)^{*}$ & $-0.3220(-5.1)^{*}$ \\
$M / B$ & $-0.0130(-1.3)$ & $-0.1643(-17.4)^{*}$ \\
NDTS & $-1.0462(-3.3)^{*}$ & $-1.4832(-4.9)^{*}$ \\
VOL & $0.0014(2.5)^{*}$ & $0.0008(1.4)$ \\
$N$ & 1299 & 1299 \\
$R^{2}$ & 0.5338 & 0.5443 \\
\hline \hline
\end{tabular}

Notes: The t-values are reported in the parenthesis; * Significant at the 5\% level.

From Table 2, the signs of most coefficients in the book regression are consistent with those in the market leverage regression. Note that the coefficient of TANG is negative in both regression models. The finding is against conventional wisdom - since traditional bank lending is secured by collateral, the role of asset tangibility should be prominent in

\footnotetext{
${ }^{12}$ For instance, the financial deficit may have a positive impact on leverage in the current $i$ years due to the pecking order effect, but the impact may become negative in the next i years.
} 
bank-oriented economies like Japan. (Booth et al., 2001). There are two potential explanations. First, due to the property market bubble and sluggish economy, collaterals fail to secure repayments of loans in Japan. Moreover, Japanese firms usually maintain close relationships with a particular bank, called the main bank, which launch rescue operations whenever the firms are in trouble. As such, the bankruptcy cost in Japan is rather low. The value of tangible assets has provided less reference value on default risk due to the presence of the main bank relationship, which could explain the absence of relationship between tangible assets and the leverage ratio. ${ }^{13}$ Second, Japanese firms with more tangible assets prefer long-term debt financing. If the substitution of long-term debt for short-term debt is less than one percent of total liability, they will be less leveraged overall. Such substitution will result in a negative correlation between tangibility and target leverage.

The pecking order theory states that firms tend to use internal funds to finance projects. Thus, it is expected that the profitability of a firm (EBIT) has an inverse relationship with debt ratio. The estimated coefficient of profitability is -1.7531 for the book leverage regression, and -1.8475 for the market leverage regression. Under the pecking order theory, firms with higher liquidity (LIQ) tend to borrow less. In our model, the estimated coefficient of LIQ is -0.1163 for book leverage, and -0.0966 for market leverage. Most of the coefficients are significant at the 5\% level. Note that the size of a firm (SIZE) has a positive impact on the target ratio for firms, suggesting that larger firms in Japan have a relatively higher level of debt financing. ${ }^{14}$ The performance of stock return (RETURN) and market-to-book ratio (M/B) have a negative impact on the target leverage ratio. It is consistent with the tradeoff theory and market timing theory, which predict an inverse relationship between leverage and stock returns. Besides, firms with high market-to-book ratios tend to use equity financing, which is consistent with the tradeoff theory and market timing theory. The negative coefficient of non-debt tax shield (NDTS) indicates that higher non-debt tax shield reduces the tax paid by firms. As the relative benefit of debt financing is lower, according to tradeoff theory, a negative relationship between non-debt tax shields and target leverage is expected.

\subsection{Long-term Adjustment}

Regressions for the long-term change of leverage ratios are estimated, and the impacts of tradeoff, pecking order and market timing variables are reported in Table 3. For the book leverage regression, the leverage changes to fill the leverage deficit with a speed of $-9.23 \%$ for a 3 -year change, $-11.62 \%$ for a 4 -year change and $-13.42 \%$ for a 5 -year change. The corresponding changes are $-8.06 \%,-10.38 \%$ and $-12.69 \%$ respectively in the market

\footnotetext{
${ }^{13}$ We thank a referee for pointing this out.

${ }^{14}$ This is because large firms generally have lower bankruptcy risks and lower costs of default, and are likely to have lower borrowing costs.
} 


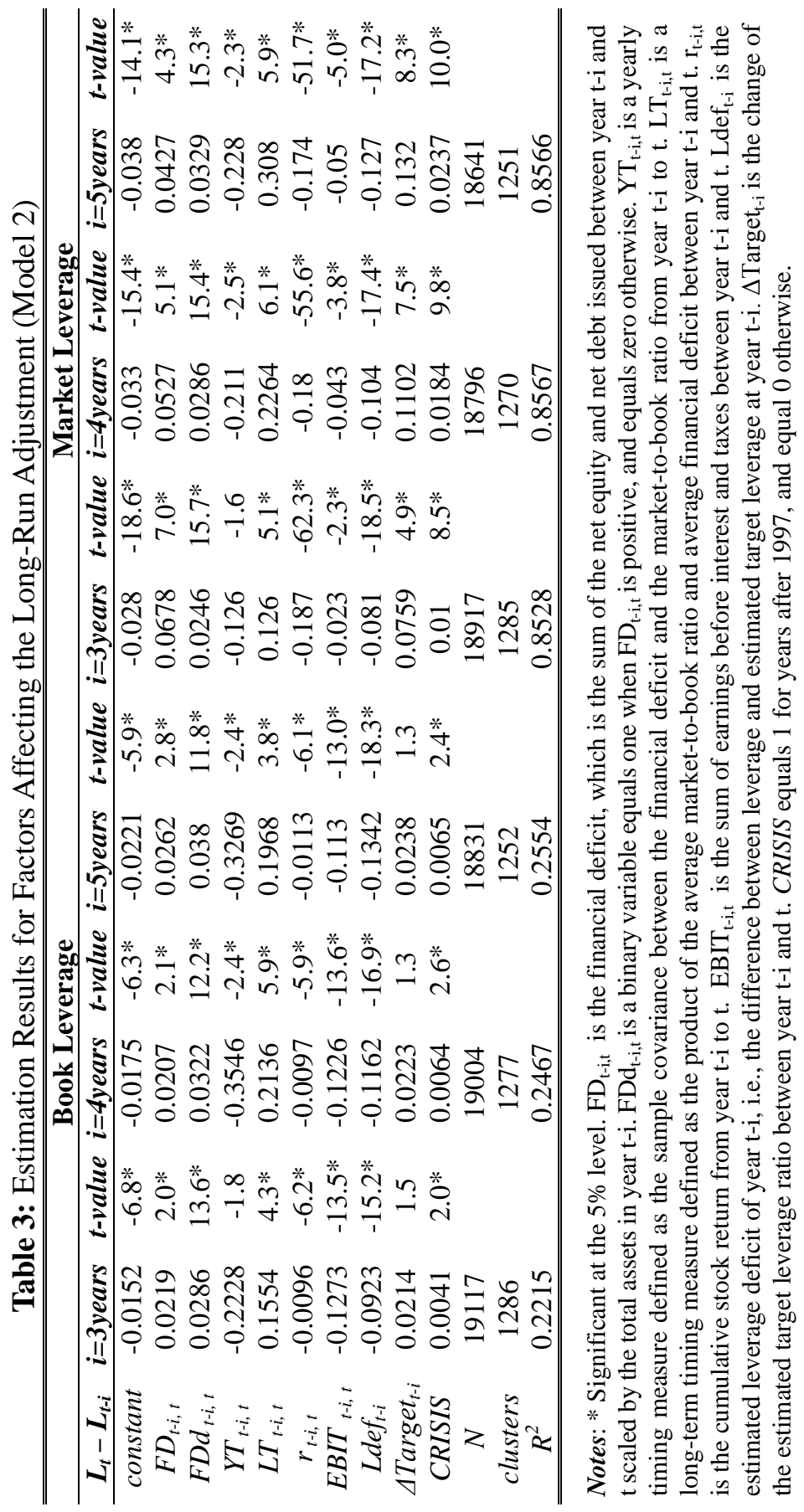


regressions. The positive sign of the coefficient of $\Delta$ Target $_{\mathrm{t}-\mathrm{i}}$ is consistent with tradeoff theory.

The strong positive effects of $\mathrm{FD}_{\mathrm{t}-\mathrm{i}, \mathrm{t}}$ and $\mathrm{FDd}_{\mathrm{t}-\mathrm{i}, \mathrm{t}}$ on the change of leverage ratio provide evidence for the pecking order theory. From Table 3, the t-value of financial deficit ranges from 4.3 to 7.0, and ranges from 5.1 to 6.1 for long-term timing in the market leverage regression. Moreover, a positive financial deficit is likely to affect the leverage ratio more significantly than a negative one, as indicated by the strongly positive coefficient of $\mathrm{FDd}_{\mathrm{t}-\mathrm{i}, \mathrm{t}}$ in both book and market regressions. Firms with a higher value of $\mathrm{LT}_{\mathrm{t}-\mathrm{i}, \mathrm{t}}$ either have a larger average market-to-book ratio (high-flying growth firms) or a larger average financial deficit. ${ }^{15}$ The coefficient of profitability $\left(\mathrm{EBIT}_{\mathrm{t}-\mathrm{i}, \mathrm{t}}\right)$ is strongly negative. The market timing variables include stock returns $\left(\mathrm{r}_{\mathrm{t}-\mathrm{i}, \mathrm{t}}\right)$ and yearly timing $\left(\mathrm{YT}_{\mathrm{t}-\mathrm{i}, \mathrm{t}}\right)$, both of which have a substantial negative impact on the change of leverage. This supports the market timing theory. Note from Table 3 that, after the Asian financial crisis, book leverage ratios increase by $0.41 \%, 0.64 \%$ and $0.65 \%$ for $\mathrm{i}=3,4,5$ respectively, while the corresponding market leverage ratios increase by $1.00 \%, 1.84 \%$ and $2.37 \%$ respectively. Thus, firms in Japan generally have a higher leverage ratio after the 1997 Asian financial crisis, revealing that the crisis places them under financial stress.

\subsection{Persistence of the Effects}

The estimation results of Model (3) are summarized in Table 4. In general, we observe a negative coefficient of leverage deficit and a positive coefficient of change in the target ratio in the market leverage regression. Therefore, firms generally make up for the leverage deficit by following target ratio.

Note that the effect of financial deficit is persistent, as indicated by the positive coefficients of $\mathrm{FD}_{\mathrm{t}-\mathrm{i}, \mathrm{t}}$ and $\mathrm{FDd}_{\mathrm{t}-\mathrm{i}, \mathrm{t}}$. Specifically, the effect of financial deficit in the recent $i$-year period on the change of debt ratio in $2 i$ years is stronger than that of previous $i$-year period, implying that the effect has intensified over the $2 i$-year period. For example, the coefficient of the first 5-year financial deficit is 0.0093 , while that of the last 5-year deficit is 0.0337 in the market 5 -year leverage change regression, shown in Table 4 . The impact of EBIT $_{t-2 i, t-i}$ is still significant even when EBIT $_{t-i, t}$ is included in the book regression.

Although the negative effect of stock performance persists over the $2 i$-year horizon, the market timing effect is not persistent. The yearly-timing coefficients are generally not significant in both periods, while the long-term timing variable is not significant in the first $i$-year period. We only observe a positive effect of long-term timing in the second

\footnotetext{
${ }^{15}$ Since some Japanese firms are part of the Keiretsu, they tend to be financed by the Keiretsu bank which holds an equity position in the company. The Keiretsu bank tends to monitor the company more closely which, by itself, can have an important impact on the firm's financing choice and cost of debt.
} 


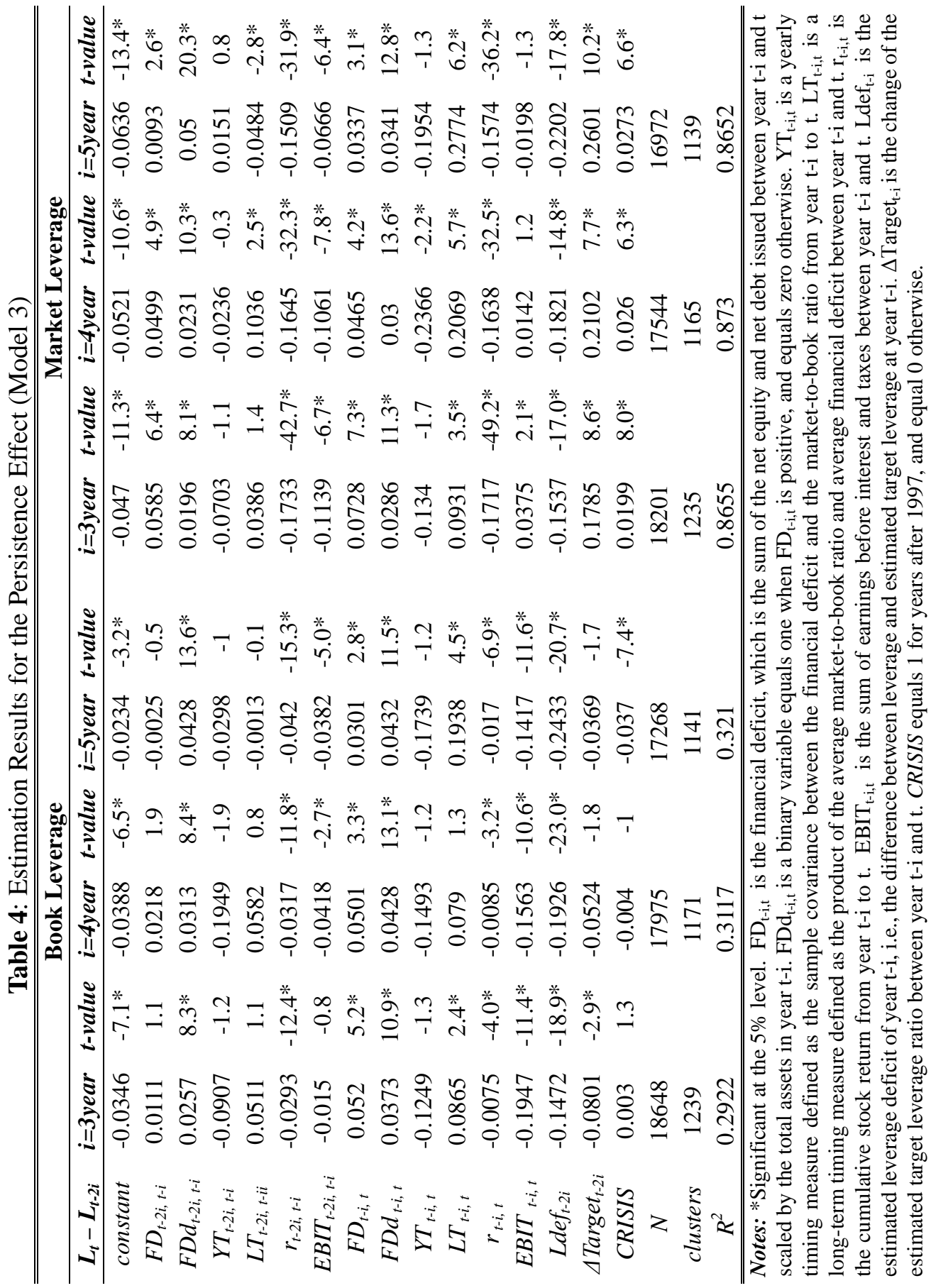


$i$-year period. Thus, there is a tendency to move towards the target leverage ratio in a longer horizon.

\subsection{Reversal of the Effects}

The results of the previous section show that impacts from variables associated with the market timing theory tend to fall over time, which indicates the existence of a potential reversal effect. The estimation results of Model (4) are reported in Table 5. A change in the sign of the coefficient of a given variable between the two i-year periods implies the existence of a reversal. We observe a reversal effect from the coefficients of the FD and FDd variables. Note that the coefficient of the financial deficit variable from year $t-2 i$ to $t-i$ is negative, while that from year $t-i$ to $t$ is positive. Moreover, for both regressions, the coefficients are larger in absolute magnitude in the second $i$-year period. A similar reversal pattern is also observed for the EBIT variable. Note also that the coefficients of the yearly timing variables in the first $i$-year period are generally insignificant, while those in the second i-year period are significantly negative. It suggests that the market timing effect is not persistent.

The effect of stock returns only reverses in the market leverage regression. The effects of leverage deficit and change in target are all significant. For the market leverage regression, the leverage deficit has a persistent negative relationship while the change in the target ratio has a long-run positive relationship with the leverage ratio change. This suggests that the observed leverage ratio follows the target slowly, even after taking into account the cash flow, profitability, stock market performance and market timing effects. 


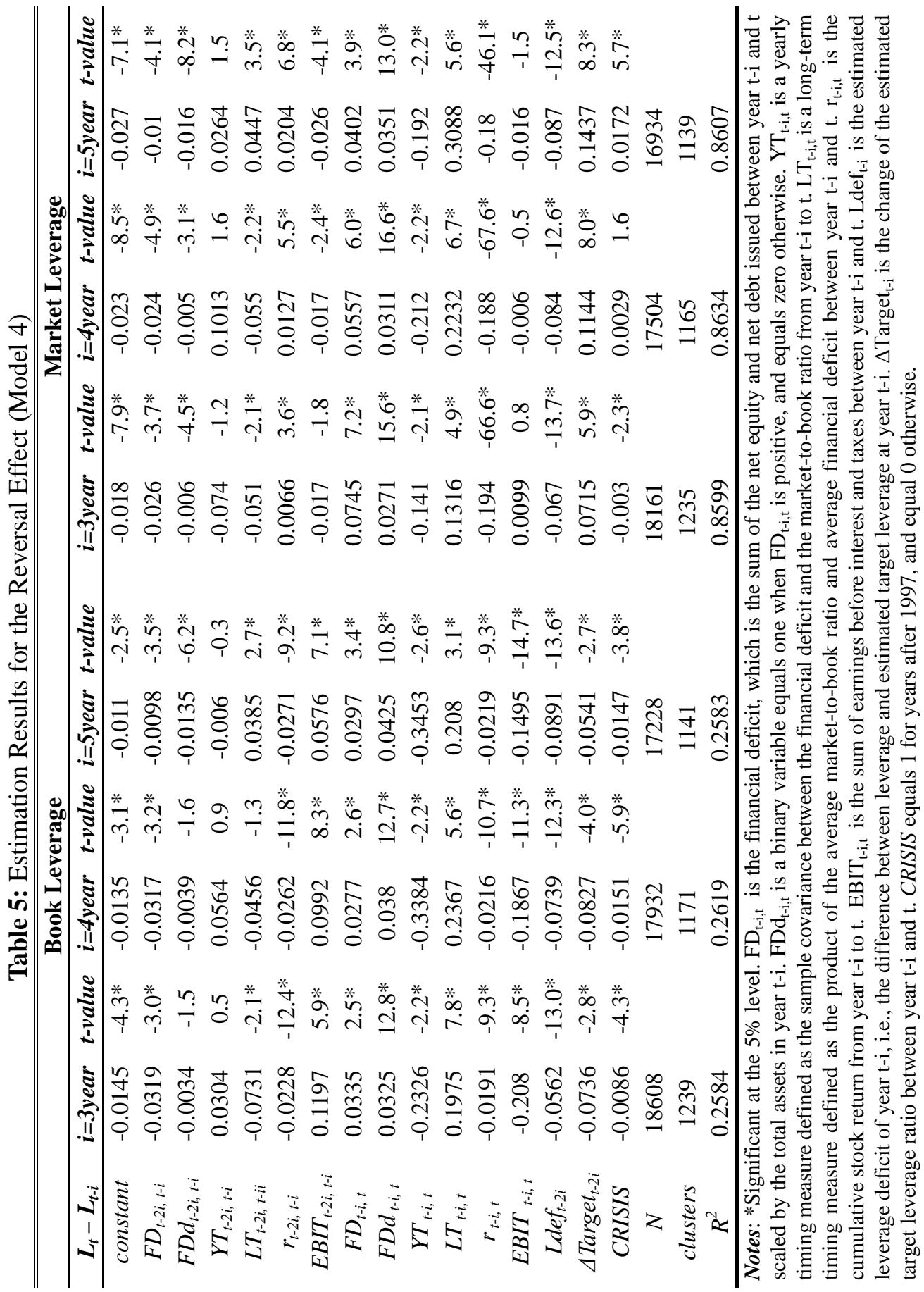




\section{CONCLUSION}

This paper examines the movement of debt-equity ratio for firms in Japan by analyzing a sample of 1,299 Japanese firms. Unlike the cases of the US and Europe, Japan is expected to exhibit higher degree of asset tangibility since collaterals play an important role in a bank-oriented economy. However, we find that an increase in tangible assets reduce the leverage ratio of firms in Japan. Our conjecture is that Japanese firms with more tangible assets are likely to be financed by long-term debt, which is not easily substituted by short-term debt. We find that Japanese firms tend to use internal funds to finance projects, as predicted by the pecking order theory. In addition, we provide evidence that market size positively affects the degree of debt financing. Consistent with the trade-off theory and market timing theory, stock performance and market-to-book ratio have a negative impact on the target leverage ratio. Besides, high-growth firms tend to use equity financing. A negative relationship between non-debt tax shields and target leverage is observed.

Our analysis has managerial implications on Japanese firms with financial deficits that tend to raise their leverage ratio. The impact on capital structure is stronger when firms are raising capital or when their financial deficit is positive. Furthermore, firms with higher profitability tend to reduce their leverage ratio. The effects implied by the pecking order theory are shown to be long lasting, persistent, but reversed. Further managerial implication is on the impact of stock return, which has persistently negative but reversed effect on the leverage ratio. Therefore, Japanese firms with good stock performance tend to issue equity and reduce their leverage ratio. The yearly timing measure carries a negative effect on the change of leverage ratio, though this market timing effect is neither persistent nor statistically significant. Our results confirm that Japanese firms take actions to make their leverage ratio consistent with their targets. Firms with a leverage ratio higher than target will reduce their leverage in the long run, but the adjustment speed towards the target is rather slow. This slow adjustment speed is partly attributable to the low costs of deviations from the target ratio. It is also found that the adjustment speed has further dwindled after the 1997 Asian Financial Crisis, indicating that the crisis puts many firms in Japan under financial stress. The results that the changes in leverage due to the financial deficit and stock returns reverse provide further evidence that Japanese firms tend to move towards their target leverage ratio.

\section{ACKNOWLEDGEMENT}

We would like to thank Julan Du for helpful comments and Kenny Shui for able research assistance. All errors are ours. 


\section{REFERENCES}

Baker, M., \& Wurgler, J. (2002). Market timing and capital structure. Journal of Finance, 57(1), 1-32.

Booth, L., Aivazian, V., Demirgüç-Kunt, A. \& Maksimovic, V. (2001). Capital structures in developing countries. Journal of Finance, 56(1), 87-130.

Brounen, D., de Jong, A. \& Koedijk, K. (2006). Capital structure policies in Europe: survey evidence. Journal of Banking and Finance, 30(5), 1409-1442.

Collin-Dufresne, P., \& Goldstein, R. S. (2001). Do credit spreads reflect stationary leverage ratios? Journal of Finance, 56(5), 1929-1957.

DeAngelo, H., \& Masulis, R. W. (1980). Optimal capital structure under corporate and personal taxation. Journal of Financial Economics, 8(1), 3-29.

Donaldson, G. (1961). Corporate Debt Capacity: A Study of Corporate Debt Policy and the Determination of Corporate Debt Capacity. Boston: Harvard Business School, Division of Research, Harvard University.

Fama, E., \& MacBeth, J. (1973). Risk, return, and equilibrium: Empirical Tests. Journal of Political Economy, 81(3), 607-636.

Fama, E., \&French, K. R. (2002). Testing tradeoff and pecking order predictions about dividends and debt. Review of Financial Studies, 15(1), 1-33.

Fischer, E. O., Heinkel, R., \& Zechner, J. (1989). Dynamic capital structure choice: theory and tests. Journal of Finance, 44(1), 19- 40.

Flannery, M. J., \& Rangan, K. P. (2006). Partial adjustment toward target capital structures. Journal of Financial Economics, 79(3), 469-506.

Frank, M., \& Goyal, V. (2003). Testing the pecking order theory of capital structure. Journal of Financial Economics, 67(2), 217-248.

Goldstein, R., Ju, N., \& Leland, H. (2001). An EBIT based model of dynamic capital structure. Journal of Business, 74(4), 483- 512.

Graham, J. R., \& Harvey, C. R . (2001). The theory and practice of corporate finance: evidence from the field. Journal of Financial Economics, 60(2-3), 187-243.

Hovakimian, A., Opler, T. \& Titman, S. (2001). The debt-equity choice. Journal of Financial and Quantitative Analysis, 36(1), 1-24.

Kayhan, A., \& Titman, S. (2007). Firms' histories and their capital structure. Journal of Financial Economics, 83, 1-32.

Korajczyk, R. A., \& Levy, A. (2003). Capital structure choice: macroeconomic conditions and financial constraints. Journal of Financial Economics, 68(1), 75-109.

Myers, S. C. (1984). The capital structure puzzle. Journal of Finance, 39(3), 575-592.

Shyam-Sunder, L., \& Myers, S. C. (1999). Testing static tradeoff against pecking order models of capital structure. Journal of Financial Economics, 51, 219-244.

Welch, I. (2004). Capital structure and stock returns. Journal of Political Economy, 112, 106-131. 